\title{
Reduction in Plasmodium falciparum Pfk 13 and pfg377 allele diversity through time in southern Vietnam
}

\author{
Nguyen Quang Thieu', Vu Duc Chinh' ${ }^{1}$, Truong Van Hanh'1, Nguyen Van Dung ${ }^{1}$, Hidekazu Takagi², \\ Takeshi Annoura ${ }^{3}$, Satoru Kawai ${ }^{4}$, Gaku Masuda ${ }^{5,6}$, Nguyen Van Tuan ${ }^{7}$, Vu Viet Hung ${ }^{1}$, Shusuke Nakazawa ${ }^{8}$, \\ Richard Culleton ${ }^{8,9}$, Nguyen Thi Huong Binh ${ }^{1}$ and Yoshimasa Maeno $0^{6,10^{*}}$ (1)
}

\begin{abstract}
Background: Plasmodium falciparum has acquired resistance to artemisinin in Southeast Asia, with mutations in the P. falciparum Kelch-13 (Pfk13) gene associated with the resistance phenotype. The widespread use of Artemisininbased combination therapy (ACT)s in Southeast Asia has led to the selection and spread of parasites carrying mutations in Pfk 13. We characterised the allele diversity of $P f k 13$ and pfg 377, an artemisinin-resistance neutral polymorphic gene, in parasite DNA extracted human blood from in southern Vietnam in 2003, 2012, 2015 and 2018.

Method: This study was conducted in Bu Gia Map commune, Binh Phuoc province, Vietnam, from May 2018 to January 2019. Twenty-four samples from 2018 to 2019, 30 from 2003, 24 from 2012 and 32 from 2015 were analysed. Malaria-infected human blood was collected by finger-prick and used for molecular analysis. A nested-PCR targeting the small subunit ribosomal RNA gene was used for Plasmodium species identification, followed by amplification and nucleotide sequencing of Pfk 13 and region 3 of pfg377. Archived blood samples collected in the same region in 2012 and 2015 were also analysed as above for comparison.

Results: The genetic diversity of Pfk 13 and pfg377 was lower in 2018-2019 compared to 2012 and 2015. The number of distinct Pfk 13 mutants decreased from three in 2012 and 2015, P553L, V568G and C580Y, to one, C580Y in 2018-2019. In 2018-2019, the frequency of C580Y mutant strains was 71\% (17/24 isolates). All samples were wild type in 2003. In 2012 and 2015, there were single-strain infections as well as co-infections with two mutant strains or with mutant and wild strains, whereas there were no co-infections in 2018. pfg377 allele diversity decreased from five alleles in 2012 to two alleles in 2018-2019.

Conclusion: The genetic diversity of P. falciparum was reduced at the two genetic loci surveyed in this study, Pfk 13 and pfg377. In the case of the former gene, we observed an increase in the prevalence of parasites carrying the C580Y gene, known to confer reduced susceptibility to ACTs. The reduction in the diversity of pfg377 may be linked to the clonal expansion of parasite strains carrying the C580Y mutation, leading to an overall reduction in parasite genetic diversity across the population.
\end{abstract}

Keywords: Plasmodium falciparum, Artemisinin resistance, K13-propeller gene, pfg377 gene, Gametocyte, Vietnam

*Correspondence: yoshimaeno@gmail.com

${ }^{6}$ School of Tropical Medicine and Global Health, Nagasaki University,

1-12-4 Sakamoto, Nagasaki, Nagasaki 852-8523, Japan

Full list of author information is available at the end of the article

\section{Background}

Artemisinin-based combination therapy (ACT) is currently the most common first-line treatment for Plasmodium falciparum in most malaria-endemic countries. original author(s) and the source, provide a link to the Creative Commons licence, and indicate if changes were made. The images or other third party material in this article are included in the article's Creative Commons licence, unless indicated otherwise in a credit line to the material. If material is not included in the article's Creative Commons licence and your intended use is not permitted by statutory regulation or exceeds the permitted use, you will need to obtain permission directly from the copyright holder. To view a copy of this licence, visit http://creativecommons.org/licenses/by/4.0/. 
However, in recent years, there have been various reports of artemisinin resistance in various countries in the Great Mekong subregion, such as Cambodia, Thailand, Myanmar, Laos, China, and Vietnam [1-6].

It appears that mutations in the propeller domain of the gene encoding the Kelch 13 (K13) protein (Pfk13), are associated with delayed parasite clearance in the presence of artemisinin in vitro and in vivo [7, 8]. In Southeast Asia, parasites carrying mutations in the $P f k 13$ gene at positions C580Y, Y493H, R539T, and I543T have been observed, and these have been linked to artemisinin resistance phenotypes. The major mutations in Vietnam are C580Y, P574L, V568G, P553L, I543T, and Y493H, all of which were detected in southern Vietnam near the border with Cambodia [9]. There are reports that resistant malaria has spread from Cambodia, but the emergence of resistant $P$. falciparum has also been observed in other areas of Vietnam, where importation of parasites seems unlikely $[10,11]$. There have been various reports on such mutant strains, but no reports on co-infections of mutant strains and their degree of artemisinin resistance.

Artemisinin and semisynthetic derivatives including artesunate, artemether and dihydroartemisinin, are short-acting antimalarial agents that kill parasites more rapidly than conventional antimalarials and are active against both the sexual and asexual stages of the parasite [12].

A range of polymorphic gametocyte-specific antigenencoding genes have previously been described in $P$. falciparum, including $p f s 230, p f s 16, p f s 25, p f g 27 / 25$ and pfg377 [13, 14]. Region 3 of pfg377 is particularly useful as a gametocyte marker, due to allelic heterogeneity in its molecular weight $[15,16]$. Seven allele types have been reported for this gene, and four of these have been reported from asymptomatic $P$. falciparum carriers in Binh Phuoc Province, Vietnam [17].

In this report, we characterise polymorphisms in $P f k 13$ and pfg377 using parasite DNA extracted from blood samples collected from individuals resident in Southern Vietnam over the course of 8 months from May 2018 to January 2019. We describe changes in their allele prevalences through time with reference to archived samples collected from 30, 24, and 32 individuals in the same region in 2003, 2012, and 2015, respectively.

\section{Materials and methods}

This study was conducted in Bu Gia Map commune $\left(11^{\circ} 56^{\prime} \mathrm{N} ; 106^{\circ} 59^{\prime} \mathrm{E}\right)$, Binh Phuoc province, Vietnam (Fig. 1), from May 2018 to January 2019. Forty-eight patients aged 3-61 years (mean \pm standard deviation: $28 \pm 12$ years), who visited the commune health center with fever above $37.5{ }^{\circ} \mathrm{C}$ and were diagnosed as malaria

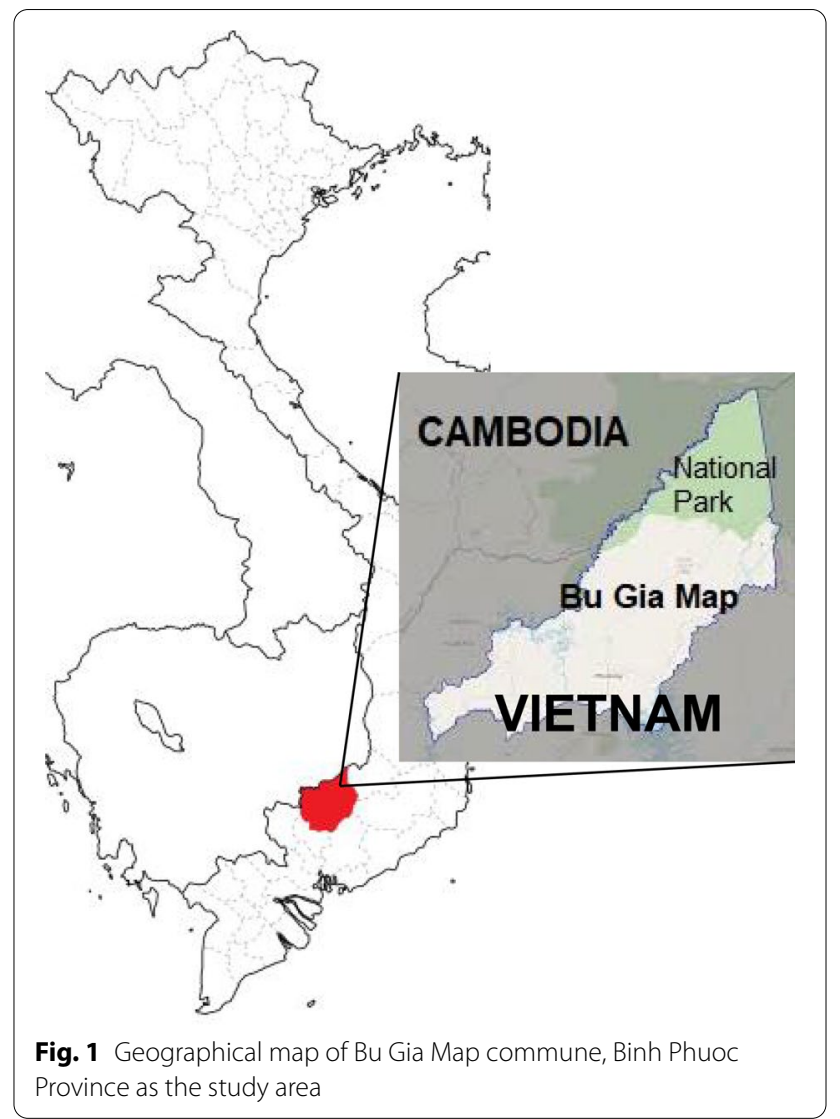

by Rapid Diagnostic Test (RDT) (SD Malaria Ag P.f/P.v, Standard Diagnostics Inc., Kyonggi-do, Republic of Korea) were enrolled in the study. There were 47 male and 1 female patients. Body temperature ranged from 37.7 to $39.6{ }^{\circ} \mathrm{C}$ (mean \pm standard deviation: $38.5 \pm 0.5^{\circ} \mathrm{C}$ ) (Table 1a). To characterise changes in allele prevalence through time, we also examined sex- and age-matched samples from $P$. falciparum malaria patients collected and stored in 2003, 2012, and 2015. The number of samples for the comparison years 2003, 2012, and 2015 were 30, 24, and 32, respectively. Treatment was performed according to Vietnamese Ministry of Health guidelines. This study was reviewed and approved by the research ethics committee of the National Institute of Malariology, Parasitology, and Entomology, Ministry of Health, Vietnam (366/QD118-VSR) and by the ethics committee of Fujita Health University, Japan (HM17-050) and Nagasaki University, Japan (10121662-5 and NU_TMGH 2020_125_1). Patients were informed of the objectives, processes, and procedures of this study, and written or oral informed consent was obtained. Blood was collected by finger-prick; some of the collected blood was used for testing by RDT and the rest was applied to filter paper for molecular analyses. Each blood-spotted filter paper was 
Table 1 Characteristics of patients infected with Plasmodium parasites (a) in Bu Gia Map commune, Binh Phuoc Province, and diagnosis results of Plasmodium species in samples of human blood samples (b)

\begin{tabular}{|c|c|c|c|c|}
\hline \multicolumn{5}{|l|}{ a. Characteristics of the study patients } \\
\hline No. examined (Plasmodium positive cases) & 48 & & & \\
\hline Age (years) & 3 to 61 (mean \pm SD: $28 \pm 12$ ) & & & \\
\hline Sex & 47 male, 1 female & & & \\
\hline Body temperature $\left({ }^{\circ} \mathrm{C}\right)$ & 37.7 to $39.6($ mean \pm SD: $38.5 \pm 0.5)$ & & & \\
\hline Estimated location of infection & Total & Pf & Pv & $\mathrm{Pf}+\mathrm{PV}$ \\
\hline In the National Park & 36 & 18 & 17 & 1 \\
\hline In the commune & 12 & 5 & 7 & 0 \\
\hline \multicolumn{5}{|l|}{ b. Malaria diagnosis results of the study sample } \\
\hline Infected Plasmodium species & Microscopy & RDT & PCR & \\
\hline Pf & 24 & 24 & 23 & \\
\hline $\mathrm{PV}$ & 24 & 24 & 24 & \\
\hline $\mathrm{Pm}$ & 0 & - & 0 & \\
\hline$P f+P v$ & 0 & 0 & 1 & \\
\hline
\end{tabular}

Pf: P. falciparum; Pv: P. vivax; Pm: P. malariae; Pf + Pv: mixed infection with Pf and Pv

immediately air dried, placed in a sealed plastic bag, and stored at room temperature.

Genomic DNA was extracted from dried blood spots stored on filter paper using the QIAamp DNA Micro Kit (Qiagen, Tokyo, Japan) as previously described [17, 18]. An 18S rRNA gene-based nested PCR was used for the detection and identification of P. falciparum and other Plasmodium species as previously described [11]. Amplification of the $P f k 13$ gene and region 3 of the gametocyte-specific gene $p f g 377$ was carried out by nested PCR as previously described [11,17], and the products or target DNA insertion plasmids were sequenced with BigDye Terminator v3.1 Cycle Sequencing Premix Kit (ABI, Foster city, CA, USA). Sequencing products were run on an ABI/Hitachi $3130 \times 1$ Genetic Analyzer (ABI) and nucleotide sequences were analysed using Genetyx (Genetyx Corporation, Tokyo, Japan). Double peaks at the same position in the electropherogram of the sequence of $P f k 13$, in which the secondary peak was greater than $50 \%$ of the amplitude of the primary peak, were considered mixed strain-infections (Additional file 1: Fig. S1).

\section{Results and discussion}

Blood samples from patients in 2018-2019 were examined by PCR for the presence and species of Plasmodium parasites. The number of single and mixed Plasmodium species infections was 47 and 1, respectively. There was a total of 23 samples containing $P$. falciparum, 24 containing $P$. vivax and one with a mixed infection of $P$. falciparum and $P$. vivax (Table 1b). Anopheles dirus from this area have previously been shown to be infected with both human and non-human primate Plasmodium parasites
[19], but no infection of humans with non-human primate Plasmodium parasites was observed in this study. Body temperatures of falciparum and vivax malaria patients averaged $38.6{ }^{\circ} \mathrm{C}$ and $38.5{ }^{\circ} \mathrm{C}$, respectively, with no significant difference between them.

Patients were interviewed about the location of their infection acquisition at the time of their first medical examination, and it was found that for both falciparum and vivax malaria patients that infection in national parks was three times more common than in communes (Table 1). There was no difference in the location of infection acquisition of $P$. falciparum and $P$. vivax. That the risk of infection and transmission is higher in the national park area is supported by the results of a vector mosquito survey carried out in the same period [19].

Among the 48 Plasmodium positive samples, 24 P. falciparum positive samples were analyzed to determine the nucleotide sequence of the nested PCR amplified portion of $P f k 13$ (nucleotide positions 1279-2127). Single nucleotide polymorphisms with respect to the $P f k 13$ sequence of the 3D7 clone (PF3D7_1343700) were recorded. Seventeen out of 24 (71\%) P. falciparum infected samples in 2018-2019 presented mutations, with only non-synonymous mutations observed. The same analysis was carried out for the 2003, 2012 and 2015 samples. In 2003, all 30 samples analyzed were wild type; in the 2012 and 2015 samples, 31 of 32 (97\%) and 23 of 24 (96\%) were mutant strains, respectively (Fig. 2).

In 2018-2019, 17 samples with the C580Y were recorded with no other mutations found (Fig. 2). In both 2012 and 2015, single infections by strains carrying mutant alleles and co-infections of strains carrying 


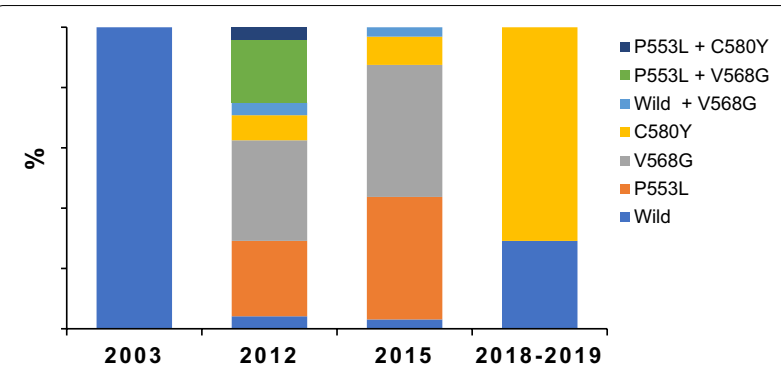

Fig. 2 Prevalence of Pfk13 mutations in Plasmodium falciparum in Binh Phuoc province, 2003 to 2019

mutant alleles were detected. In these years, three mutant alleles, P553L, V568G, and C580Y, were present. Three types of co-infections were recorded: wild type + V568G, P553L + V568G, and P553L + C580Y (Fig. 2). To determine whether these non-synonymous mutant alleles were unique to the study area, we selected and surveyed neighbouring and remote areas with similar environments to the study site and compared the results. The species and frequency of mutant alleles in this study area and neighbouring areas were similar, but remote areas showed different results with less frequent mutations [11, 20]. V568G and P553L were the dominant mutants in the 2012 and 2015 samples, whereas C580Y was detected at a low frequency in these years (Fig. 2). These results are consistent with another study carried out on this area [20]. As of 2016, 28 non-synonymous substitution mutant alleles of $P f k 13$ have been described in Southeast Asia, 16 of which were reported from artemisininresistant samples. On the west side of the Mekong River, China, Myanmar and Thailand, F446I, N458Y, P674L and $\mathrm{R} 561 \mathrm{H}$ are dominant, while on the east side, Cambodia, Laos and Vietnam, C580Y, R539T, Y493H and I543T are dominant. All these mutant alleles have been detected in resistant samples. Among these mutants, C580Y is dominant in Thailand and Cambodia, as in this study. Of the three variants detected in this study, P553L and V568G are the only mutants that were mainly detected in Vietnam. These are also the mutants that have been reported since the early detection of mutant strains [9, 21-23].

The relative proportions of the various mutations in Pfk13 vary from year to year. In the presented study, there was no association between the number or diversity of $P f k 13$ alleles and drug resistance or infection efficiency. To determine if this reduction in genetic diversity was observable at other genetic loci, we next examined the polymorphic gametocyte-specific gene $p f g 377$. The number of alleles of $p f g 377$ in the study area ranged from five in 2012 to two in 2018-2019 (Fig. 3), mirroring the reduction in allele diversity observed for $P f k 13$, which changed from 7 in 2012 to 2 in 2018-2019 (Fig. 3). There was also no relationship between $P f k 13$ mutation diversity and that of the $p f g 377$ allele.

The proportion of parasites with $P f k 13$ mutation in this study was consistent with previous studies carried out in

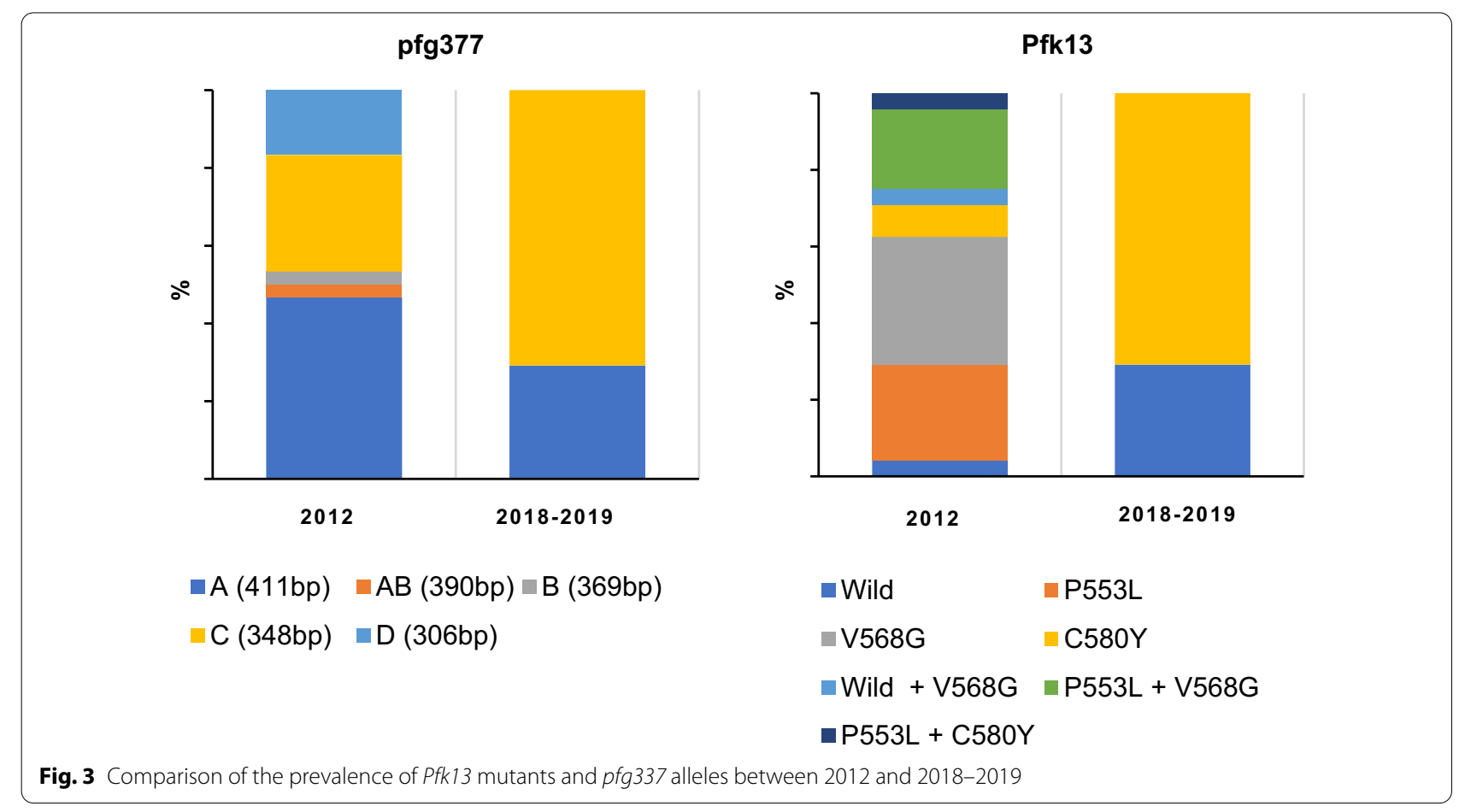


the same area [20]. Unlike previous studies, however, coinfection with multiple mutant strains were detected in the same patient samples. Consistent with this, five alleles of $p f g 377$ were found in 2012, when a mixed infection of three Pfk 13 mutants was also observed. This reduced to two types each for both $P f k 13$ and $p f g 377$ in 2018-2019.

The C580Y mutation confers a moderate level of resistance against artemisinin and its derivatives. This mutation is the most widespread in the Mekong region, and it is replacing other mutations in areas, where other mutations were originally dominant [24].

The acquisition of mutations that confer drug resistance can occasionally result in fitness costs relative to wild types in the absence of drug pressure. The Pfk13 C580Y mutation results in less of a fitness cost than other mutations [25]. However, the fitness cost of C580Y alone cannot explain the rapid spread of this substitution [25]. Genome-wide association analysis suggests that mutations in genes other than $P f k 13$ may further compensate for fitness.

The relative prevalence of $P$. falciparum at each time point studied in Binh Phuoc Province, where Bu Gia Map is located, has decreased (Additional file 1: Table S1). A reduction in the effective population size of the parasite pool would result in a decrease in the level of genomewide diversity. This may be one of the factors contributing to the reduced in the diversity of mutant strains.

Nineteen of 24 cases of falciparum malaria were contracted in the Bu Gia Map national park. The study area, including this national park, is part of a closed border area with Cambodia, and local ethnic minorities have little interaction with other places, especially at night. Therefore, the invasion of new variants from exotic sources is unlikely, suggesting that the changes in allele prevalences observed in this region are the result of changing environmental conditions for the local parasite population, rather than the result of import of strains from outside.

\section{Conclusion}

The genetic diversity of $P$. falciparum was reduced at the two genetic loci surveyed in this study, $P f k 13$ and $p f g 377$. In the case of the former gene, we observed an increase in the prevalence of parasites carrying the C580Y gene, known to confer reduced susceptibility to ACTs. The reduction in the diversity of $p f g 377$ may be linked to the clonal expansion of parasite strains carrying the C580Y mutation, leading to an overall reduction in parasite genetic diversity on the population.

The results of this epidemiological study suggest that the genetic polymorphisms created by ACTs pressure are eliminated due to fitness issues, and the spread of the remaining C580Y mutation is a future issue for malaria control.

\section{Abbreviations}

ACT: Artemisinin-based combination therapy; Pfk 13: Plasmodium falciparum Kelch-13; RDT: Rapid diagnosis test.

\section{Supplementary Information}

The online version contains supplementary material available at https://doi. org/10.1186/s41182-022-00409-4.

Additional file 1: Figure S1. Nucleotide sequences were analyzed in both directions. The two strains were considered to be co-infected if they were found to have reached more than half of the largest peak at the same site in the waveform, and if no noise was found in the surrounding waveform. If it was difficult to determine, a DNA insertion plasmid was used to analyze the sequence. Table $\mathbf{S 1}$. Number of Plasmodium cases in Binh Phuoc Province in 2003, 2012, 2015, and 2018.

\section{Acknowledgements}

We would like to thank Kaoru Hori for her technical support. We appreciate the support of the staff from the Binh Phuoc provinces and the local authorities.

\section{Authors' contributions}

Study design and conception: NQT, VDC, TVH, NVD, NTHB and YM. Fieldwork and data collection: VDC, TVH, WVH, HT, SK, TA, GM, NVT, SN and YM. Experiments: VDC, TVH, VVH, GM, HT, NVT, SK, TA, RC, NTHB and YM. Statistical analyses: VDC, GM, HT and YM. Manuscript preparation: NQT, VDC, TVH, GM, HT, SK, TA, RC, NTHB and YM. All authors read and approved the final manuscript.

Funding

This study was partly supported by the following grants- (i) WHO, Vietnam, (ii) JSPS KAKENHI Grant Numbers-26360029, $17 \mathrm{H04513}$ and 20H04411.

Availability of data and materials

The data supporting the conclusions of this article are included in the article.

\section{Declarations}

Ethics approval and consent to participate

This study was reviewed and approved by the research ethics committee of the National Institute of Malariology, Parasitology, and Entomology, Ministry of Health, Vietnam (366/QD118-VSR) and by the ethics committee of Fujita Health University, Japan (HM17-050) and Nagasaki University, Japan (10121662-5 and NU_TMGH 2020_125_1). Patients were informed of the objectives, processes, and procedures of this study, and written or oral informed consent was obtained.

Consent for publication

Not applicable.

\section{Competing interests}

The authors declare that they have no competing interests.

\section{Author details}

${ }^{1}$ National Institute of Malariology, Parasitology and Entomology, Hanoi, Vietnam. ${ }^{2}$ Department of Microbiology and Immunology, Aichi Medical University School of Medicine, Aichi, Japan. ${ }^{3}$ Department of Parasitology, National Institute of Infectious Diseases, Tokyo, Japan. ${ }^{4}$ Laboratory of Tropical Medicine and Parasitology, Dokkyo Medical University, Tochigi, Japan. ${ }^{5}$ Department of International Affairs and Tropical Medicine, Tokyo Women's Medical University, Tokyo, Japan. ${ }^{6}$ School of Tropical Medicine and Global Health, Nagasaki University, 1-12-4 Sakamoto, Nagasaki, Nagasaki 852-8523, Japan. ${ }^{7}$ Faculty of Medical Engineering, Phenikaa University, Hanoi, Vietnam. ${ }^{8}$ Department 
of Protozoology, Institute of Tropical Medicine, Nagasaki University, Nagasaki, Japan. ${ }^{9}$ Division of Molecular Parasitology, Proteo-Science Centre, Ehime University, Ehime, Japan. ${ }^{10}$ Department of Virology and Parasitology, Fujita Health University School of Medicine, Aichi, Japan.

Received: 29 November 2021 Accepted: 20 February 2022 Published online: 01 March 2022

\section{References}

1. Noedl H, Se Y, Schaecher K, Smith BL, Socheat D, Fukuda MM, Artemisinin Resistance in Cambodia 1 (ARC1) Study Consortium. Evidence of artemisinin-resistant malaria in western Cambodia. N Engl J Med. 2008;359(24):2619-20. https://doi.org/10.1056/NEJMc0805011.

2. Dondorp AM, Nosten F, Yi P, Das D, Phyo AP, Tarning J, Lwin KM, Ariey F, Hanpithakpong W, Lee SJ, Ringwald P, Silamut K, Imwong M, Chotivanich K, Lim P, Herdman T, An SS, Yeung S, Singhasivanon P, Day NP, Lindegardh $\mathrm{N}$, Socheat D, White NJ. Artemisinin resistance in Plasmodium falciparum malaria. N Engl J Med. 2009;361(5):455-67. https://doi.org/10.1056/ NEJMoa0808859 (Erratum in: N Engl J Med. 2009 361(17):1714).

3. Amaratunga C, Sreng S, Suon S, Phelps ES, Stepniewska K, Lim P, Zhou C, Mao S, Anderson JM, Lindegardh N, Jiang H, Song J, Su XZ, White NJ, Dondorp AM, Anderson TJ, Fay MP, Mu J, Duong S, Fairhurst RM. Artemisinin-resistant Plasmodium falciparum in Pursat province, western Cambodia: a parasite clearance rate study. Lancet Infect Dis. 2012;12(11):851-8. https://doi.org/10.1016/S1473-3099(12)70181-0.

4. Phyo AP, Nkhoma S, Stepniewska K, Ashley EA, Nair S, McGready R, ler Moo C, Al-Saai S, Dondorp AM, Lwin KM, Singhasivanon P, Day NP, White NJ, Anderson TJ, Nosten F. Emergence of artemisinin-resistant malaria on the western border of Thailand: a longitudinal study. Lancet. 2012;379(9830):1960-6. https://doi.org/10.1016/S0140-6736(12)60484-X.

5. Kyaw MP, Nyunt MH, Chit K, Aye MM, Aye KH, Aye MM, Lindegardh N, Tarning J, Imwong M, Jacob CG, Rasmussen C, Perin J, Ringwald P, Nyunt MM. Reduced susceptibility of Plasmodium falciparum to artesunate in southern Myanmar. PLoS ONE. 2013;8(3): e57689. https://doi.org/10.1371/ journal.pone.0057689.

6. Ashley EA, Dhorda M, Fairhurst RM, Amaratunga C, Lim P, Suon S, Sreng S, Anderson JM, Mao S, Sam B, Sopha C, Chuor CM, Nguon C, Sovannaroth S, Pukrittayakamee S, Jittamala P, Chotivanich K, Chutasmit K, Suchatsoonthorn C, Runcharoen R, Hien TT, Thuy-Nhien NT, Thanh NV, Phu NH, Htut Y, Han KT, Aye KH, Mokuolu OA, Olaosebikan RR, Folaranmi OO, Mayxay M, Khanthavong M, Hongvanthong B, Newton PN, Onyamboko MA, Fanello Cl, Tshefu AK, Mishra N, Valecha N, Phyo AP, Nosten F, Yi P, Tripura R, Borrmann S, Bashraheil M, Peshu J, Faiz MA, Ghose A, Hossain MA, Samad R, Rahman MR, Hasan MM, Islam A, Miotto O, Amato R, Maclnnis B, Stalker J, Kwiatkowski DP, Bozdech Z, Jeeyapant A, Cheah PY, Sakulthaew T, Chalk J, Intharabut B, Silamut K, Lee SJ, Vihokhern B, Kunasol C, Imwong M, Tarning J, Taylor WJ, Yeung S, Woodrow CJ, Flegg JA, Das D, Smith J, Venkatesan M, Plowe CV, Stepniewska K, Guerin PJ, Dondorp AM, Day NP, White NJ, Tracking Resistance to Artemisinin Collaboration (TRAC). Spread of artemisinin resistance in Plasmodium falciparum malaria. N Engl J Med. 2014;371(5):411-23. https://doi.org/10.1056/ NEJMoa1314981 (Erratum in: N Engl J Med. 2014 Aug 21;371(8):786).

7. Takala-Harrison S, Clark TG, Jacob CG, Cummings MP, Miotto O, Dondorp AM, Fukuda MM, Nosten F, Noedl H, Imwong M, Bethell D, Se Y, Lon C, Tyner SD, Saunders DL, Socheat D, Ariey F, Phyo AP, Starzengruber P, Fuehrer HP, Swoboda P, Stepniewska K, Flegg J, Arze C, Cerqueira GC, Silva JC, Ricklefs SM, Porcella SF, Stephens RM, Adams M, Kenefic LJ, Campino S, Auburn S, Maclnnis B, Kwiatkowski DP, Su XZ, White NJ, Ringwald P, Plowe CV. Genetic loci associated with delayed clearance of Plasmodium falciparum following artemisinin treatment in Southeast Asia. Proc Natl Acad Sci USA. 2013;110(1):240-5. https://doi.org/10.1073/pnas.12112 05110.

8. Ariey F, Witkowski B, Amaratunga C, Beghain J, Langlois AC, Khim N, Kim S, Duru V, Bouchier C, Ma L, Lim P, Leang R, Duong S, Sreng S, Suon S, Chuor CM, Bout DM, Ménard S, Rogers WO, Genton B, Fandeur T, Miotto O, Ringwald P, Le Bras J, Berry A, Barale JC, Fairhurst RM, Benoit-Vical F, Mercereau-Puijalon O, Ménard D. A molecular marker of artemisininresistant Plasmodium falciparum malaria. Nature. 2014;505(7481):50-5. https://doi.org/10.1038/nature12876.
9. Takala-Harrison S, Jacob CG, Arze C, Cummings MP, Silva JC, Dondorp AM, Fukuda MM, Hien TT, Mayxay M, Noedl H, Nosten F, Kyaw MP, Nhien NT, Imwong M, Bethell D, Se Y, Lon C, Tyner SD, Saunders DL, Ariey F, Mercereau-Puijalon O, Menard D, Newton PN, Khanthavong M, Hongvanthong B, Starzengruber P, Fuehrer HP, Swoboda P, Khan WA, Phyo AP, Nyunt MM, Nyunt MH, Brown TS, Adams M, Pepin CS, Bailey J, Tan JC, Ferdig MT, Clark TG, Miotto O, Maclnnis B, Kwiatkowski DP, White NJ, Ringwald P, Plowe CV. Independent emergence of artemisinin resistance mutations among Plasmodium falciparum in Southeast Asia. J Infect Dis. 2015;211(5):670-9. https://doi.org/10.1093/infdis/jiu491.

10. Imwong M, Hien TT, Thuy-Nhien NT, Dondorp AM, White NJ. Spread of a single multidrug resistant malaria parasite lineage (PfPailin) to Vietnam. Lancet Infect Dis. 2017;17(10):1022-3. https://doi.org/10.1016/S14733099(17)30524-8.

11. Maeno Y, Quang NT, Culleton R, Kawai S, Masuda G, Hori K, Nakazawa S, Marchand RP. Detection of the Plasmodium falciparum Kelch-13 gene P553L mutation in sporozoites isolated from mosquito salivary glands in South-Central Vietnam. Parasites Vectors. 2017;10(1):308. https://doi.org/ 10.1186/s13071-017-2247-9.

12. German PI, Aweeka FT. Clinical pharmacology of artemisinin-based combination therapies. Clin Pharmacokinet. 2008;47(2):91-102. https:// doi.org/10.2165/00003088-200847020-00002.

13. Alano P, Read D, Bruce M, Aikawa M, Kaido T, Tegoshi T, Bhatti S, Smith DK, Luo C, Hansra S, Carter R, Elliott JF. COS cell expression cloning of Pfg377, a Plasmodium falciparum gametocyte antigen associated with osmiophilic bodies. Mol Biochem Parasitol. 1995;74(2):143-56. https://doi. org/10.1016/0166-6851(95)02491-3.

14. Niederwieser I, Felger I, Beck HP. Plasmodium falciparum: expression of gametocyte-specific genes in monolayer cultures and malaria-positive blood samples. Exp Parasitol. 2000;95(3):163-9. https://doi.org/10.1006/ expr.2000.4536.

15. Menegon M, Severini C, Sannella A, Paglia MG, Sangaré D, Abdel-Wahab A, Abdel-Muhsin AA, Babiker H, Walliker D, Alano P. Genotyping of Plasmodium falciparum gametocytes by reverse transcriptase polymerase chain reaction. Mol Biochem Parasitol. 2000;111(1):153-61. https://doi. org/10.1016/s0166-6851(00)00314-5.

16. Abdel-Wahab A, Abdel-Muhsin AM, Ali E, Suleiman S, Ahmed S, Walliker D, Babiker HA. Dynamics of gametocytes among Plasmodium falciparum clones in natural infections in an area of highly seasonal transmission. J Infect Dis. 2002;185:1838-42.

17. Maeno Y, Nakazawa S, le Dao D, Yamamoto N, Giang ND, Van Hanh T, le Thuan K, Taniguchi K. A dried blood sample on filter paper is suitable for detecting Plasmodium falciparum gametocytes by reverse transcription polymerase chain reaction. Acta Trop. 2008;107(2):121-7. https://doi.org/ 10.1016/j.actatropica.2008.05.001.

18. Nakazawa S, Marchand RP, Quang NT, Culleton R, Manh ND, Maeno Y. Anopheles dirus co-infection with human and monkey malaria parasites in Vietnam. Int J Parasitol. 2009;39(14):1533-7. https://doi.org/10.1016/j. ijpara.2009.08.005.

19. Chinh VD, Masuda G, Hung W, Takagi H, Kawai S, Annoura T, Maeno Y. Prevalence of human and non-human primate Plasmodium parasites in anopheline mosquitoes: a cross-sectional epidemiological study in Southern Vietnam. Trop Med Health. 2019;47:9. https://doi.org/10.1186/ s41182-019-0139-8.

20. Thuy-Nhien N, Tuyen NK, Tong NT, Vy NT, Thanh NV, Van HT, Huong-Thu P, Quang HH, Boni MF, Dolecek C, Farrar J, Thwaites GE, Miotto O, White NJ, Hien TT. K13 propeller mutations in Plasmodium falciparum populations in regions of malaria endemicity in Vietnam from 2009 to 2016. Antimicrob Agents Chemother. 2017;61(4):e01578-e1616. https://doi.org/10. 1128/AAC.01578-16.

21. He Y, Campino S, Diez Benavente E, Warhurst DC, Beshir KB, Lubis I, Gomes AR, Feng J, Jiazhi W, Sun X, Huang F, Tang LH, Sutherland CJ, Clark TG. Artemisinin resistance-associated markers in Plasmodium falciparum parasites from the China-Myanmar border: predicted structural stability of K13 propeller variants detected in a low-prevalence area. PLoS ONE. 2019;14(3): e0213686. https://doi.org/10.1371/journal.pone.0213686.

22. Putaporntip C, Kuamsab N, Kosuwin R, Tantiwattanasub W, Vejakama P, Sueblinvong T, Seethamchai S, Jongwutiwes S, Hughes AL. Natural selection of K13 mutants of Plasmodium falciparum in response to artemisinin combination therapies in Thailand. Clin Microbiol Infect. 2016;22(3):285. e1-8. https://doi.org/10.1016/j.cmi.2015.10.027. 
23. MalariaGEN Plasmodium falciparum Community Project. Genomic epidemiology of artemisinin resistant malaria. Elife. 2016;5: e08714. https://doi. org/10.7554/eLife.08714.

24. Anderson TJ, Nair S, McDew-White M, Cheeseman IH, Nkhoma S, Bilgic

F, McGready R, Ashley E, Pyae Phyo A, White NJ, Nosten F. Population parameters underlying an ongoing soft sweep in Southeast Asian malaria parasites. Mol Biol Evol. 2017;34(1):131-44. https://doi.org/10.1093/ molbev/msw228.

25. Nair S, Li X, Arya GA, McDew-White M, Ferrari M, Nosten F, Anderson TJC. Fitness costs and the rapid spread of kelch13-C580Y substitutions conferring artemisinin resistance. Antimicrob Agents Chemother. 2018;62(9):e00605-e618. https://doi.org/10.1128/AAC.00605-18.

\section{Publisher's Note}

Springer Nature remains neutral with regard to jurisdictional claims in published maps and institutional affiliations.

- fast, convenient online submission

- thorough peer review by experienced researchers in your field

- rapid publication on acceptance

- support for research data, including large and complex data types

- gold Open Access which fosters wider collaboration and increased citations

- maximum visibility for your research: over $100 \mathrm{M}$ website views per year

At $\mathrm{BMC}$, research is always in progress.

Learn more biomedcentral.com/submissions 